\section{MATEMATICKÝ MODEL REGULACE ŽELEZA V ORGANISMU}

\section{Arnošt Mládek, Martin Vokurka, Jiří Kofránek}

\begin{abstract}
Abstrakt
S využitím námi vyvinutého vývojového nástroje BodyLight.js byla vytvořena výuková simulační aplikace, která interaktivní formou vysvětluje metabolismus železa v lidském organismu. $\checkmark$ pozadí aplikace je matematický model vytvořený $v$ jazyce Modelica. Náš vývojový nástroj umožnil propojit matematický model s grafickými objekty a výukovým textem a vygenerovat výukovou aplikaci do standardizovaného HTML souboru, který je možné spouštět $v$ běžném internetovém prohlížeči na počítači, tabletu nebo chytrém telefonu bez nutnosti instalace jakékoliv aplikace nebo rozšíření. Interaktivní aplikace se stane komplementem standardní výuky regulace železa v rámci kurzu patologické fyziologie.
\end{abstract}

Pro barevnou verzi schémat, viz. elektronická verze textu (DOI) nebo www stránky: http://physiome.cz/apps//ronMetabolism

\section{1 Úvod}

Přestože je lidské tělo složeno převážně z biogenních prvků (vodík, uhlík, dusík a kyslík), hrají atomy přechodných kovů v molekulární biologii buňky klíčovou roli, a to díky flexibilitě své elektronové struktury. Jedním z takových kovů je železo, které je součástí hemoproteinů $\mathrm{s}$ afinitou k molekulám kyslíku (hemoglobinu a myoglobinu) a řady enzymů podílejících se na oxygenaci tkání, na obraně proti oxidativnímu stresu, na proliferaci buněk a na dalších důležitých metabolických pochodech. Za fyziologického stavu panuje v těle homeostatická rovnováha mezi regulovaným př́ijmem železa v potravě a jeho neregulovanými ztrátami ve formě krvácení a zániku epiteliálních a slizničních buněk. Zásadní roli v tomto prísně rízeném procesu hraje nedávno objevený hormon hepcidin, který reguluje vstřebávání železa ze stravy, recyklaci železa ze zaniklých erytrocytů a jeho uvolňování ze zásob. Existuje celá řada onemocnění, která se vyznačují abnormální hladinou hepcidinu. Zatímco neadekvátní snížení hladiny hepcidinu vede k přetižení organismu železem, které je typické v př́padě hereditární hemochromatózy, zvýšená hladina hepcidinu vede $k$ defektní erytropoéze a následně $\mathrm{k}$ rozvoji anémie.

Pomocí jazyka Modelica jsme implementovali a rozšírili doposud nejkomplexnější a experimentálně verifikovaný matematický model systémové regulace železa [1], navrhli animované grafické rozhraní a s využitím našeho open-source nástroje BodyLight.js [2] připravili interaktivní e-learning aplikaci. $V$ rámci této aplikace, která je dostupná pomocí běžného www prohlížeče, je možné simulovat aktuální toky atomů železa nejen mezi jednotlivými orgánovými systémy, ale rovněž na buněčné úrovni. Uživatel může regulovat množství železa přijatého potravou a míru vylučování a sledovat odpověd' organismu. Dále je možné simulovat různé patologické stavy včetně knock-outu relevantních genů nebo zánětlivého stavu vyvolaného bakterémií.

\section{Metabolismus železa a jeho homeostáza}

Železo je anorganický prvek, hojně obsažený v zemské kůře. $\checkmark$ periodické tabulce ho najdeme $v$ první periodě mezi přechodnými kovy s nepárovými d-elektrony. Jeho elektronová struktura je, podobně jako u jiných tranzitivních kovů d-bloku, velmi flexibilní a energetické hladiny "jemně" laditelné. Proto je evoluční využití kovů napříč organismy výhodné a právě proto má v lidském organismu mnoho zásadních funkcí. Energeticky nejvýhodnější je pro železo oktahedrální geometrie (Obrázek 1). Železo je např́klad součástí tetramerního hemoglobinu v erytrocytech, kde se podílí na transportu molekulárního kyslíku do tkání nebo se nachází v jeho monomerní variantě, myoglobinu, ve svalových vláknech, kde zajištuje kyslíkovou rezervu pro aerobní metabolismus. Dále je součástí množství enzymů v každé buňce a podílí se na mnoha chemických, převážně oxidačně-redukčních reakcích. Jeho role na buněčné úrovni je díky jedinečné elektronové konfiguraci nezastupitelná.

$\checkmark$ lidském organismu se nacházejí přibližně 3 až 4 gramy železa. Až dvě třetiny zásob železa je obsaženo v hemoglobinu červených krvinek a $v$ jejich prekurzorech (erytroblastech) $v$ kostní dřeni. Z pohledu orgánových systémů je kvantitativně významný obsah železa především ve svalech, játrech a v retikulo-endoteliálním systému. Část železa je stabilně využívána pro krvetvorbu, svaly a produkci enzymů, ale až $1 / 4$ železa může být uložena v zásobárnách, především v jaterních buňkách (hepatocytech) a buňkách RES (především v makrofázích). Muži mají obecně více železa a to včetně zásobního. Podíl železa, které je aktivně přenášeno $v$ krvi, je velmi malé v porovnání $s$ jeho zásobami a činí přibližně $4 \mathrm{mg}$.

Železo je díky svým vlastnostem a reaktivitě pro buňku toxické. Volné dvojmocné železo $\left(\mathrm{Fe}^{2+}\right)$ má schopnost katalyzovat vznik volných radikálů, které působí v intracelulárním prostředí oxidativní stres v rámci Fentonovy reakce. Nejvíce poškozenými orgány při nadbytku železa jsou játra, pankreas, myokard a endokrinní žlázy. Železo je proto $v$ organismu za fyziologických stavů v reaktivní nevázané formě jen v minimální koncentraci a jeho vstřebávání i distribuce po těle jsou př́isně regulovány.

\subsection{Vstřebávání železa z potravy}

V našich podmínkách je hlavním zdrojem železa hem, který je obsažený především v mase. Hemová forma může představovat až $2 / 3$ celkového př́ijmu železa. $V$ potravě je dále obsaženo i železo volné, nehemové. Jde především o železo trojmocné $\left(\mathrm{Fe}^{3+}\right)$, ale vstřebává se zejména železo dvojmocné $\left(\mathrm{Fe}^{2+}\right)$. Vstřebávání železa je zpětnovazebně regulováno a probíhá hlavně ve slizničním epitelu počátečního úseku tenkého střeva, v duodenálních enterocytech. Prostřednictvím resorpce železa se řídí celkové množství železa v těle. Výdej železa naopak organismus regulovat neumí. Fyziologické ztráty železa vznikají odlupováním buněk, u žen pak zejména menstruačním krvá-
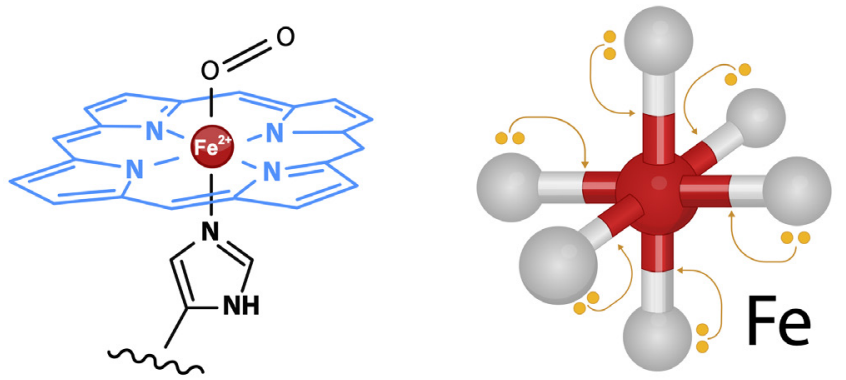

Obrázek 1 - Nejčastější oktahedrální geometrie železa $\mathrm{Fe}^{2+} / \mathrm{Fe}^{3+} v$ koordinačně-kovalentní molekule. Vlevo: modře - schématické zobrazení tetrapyrrolového kruhu, který představuje čtyři ekvatoriální ligandy poskytující elektronový pár, černè - dva axiální ligandy poskytující elektronový pár: molekulární kyslík (nad rovinou kruhu) a postranní řetězec histidinu (pod rovinou kruhu). Vpravo: obecná oktahedrální koordinačně-kovalentní struktura s centrálním atomem železa a šesti (obecně různými) ligandy, které poskytují nevazebný elektronový pár. Přesun nevazebných elektronových párů je znázorněn žlutými šipkami. Geometrická struktura komplexních sloučenin není odvozena z náboje centrálního iontu (zde +2), ale $z$ orbitalových interakcí mezi donory elektronů (ligandy jako např. dusík nebo kyslík) a volnými d-orbitaly železa. Pro bližší vysvětlení, viz. například: https://opentextbc.ca/chemistry/chapter/19-2-coordination-chemistry-of-transition-metals/ 
cením a kojením. Denně se takto ztrácí 1-2 mg železa. Protože organismus nemůže fyziologicky odstranit nadbytečné železo, regulace jeho př́ijmu je jediným možným mechanismem pro udržování jeho homeostatické koncentrace. Za fyziologických okolností se u dospělého jedince vstřebává přibližně jedna desetina železa přijatého $v$ potravě. To představuje 1-2 mg, což odpovídá množství odpovídající jeho denním ztrátám. Při zvýšené potřebě železa, napríklad po předchozím krvácení, se tento podíl může zvýšit a naopak, nadbytek železa a některé stavy způsobují, že se množství vstřebaného železa sníží.

Vstřebávání železa z lumen duodena probíhá na apikální straně enterocytu a jeho přenos přes buněčnou membránu zabezpečují přenašeče. Z mechanismů vstřebávání je nejlépe popsána resorpce nehemového dvojmocného železa. Trojmocné železo, které je v potravě častější, je redukováno na železo dvojmocné. Význam pro tuto redukci má žaludeční kyselina chlorovodíková a vitamin C. V kartáčovém lemu duodenálních enterocytů existuje enzym, který př́slušnou redukci na $\mathrm{Fe}^{3+}$ katalyzuje - duodenální Cytochrom B (CytB). Dvojmocné železo pak vstupuje do buňky transportérem nazývaným (DMT1). Kromě železa je schopen přenášet přes buněčnou membránu i jiné dvojmocné kovy. Pro vstup hemového železa do buňky není znám odpovídající přenašeč. $V$ enterocytu se železo $z$ hemu uvolňuje působením enzymu cyklooxygenázy.

$\checkmark$ enterocytu je železo uloženo ve dvou formách, mezi kterými dochází k dynamické rovnováze: i) volné dvojmocné železo, jehož koncentrace je $z$ důvodu toxicity držena na nízké úrovni a ii) zásobní trojmocné železo navázané na protein ferritin.

Na bazolaterální membráně vystupuje dvojmocné železo buněčným exportérem železa, který se nazývá ferroportin. Při výstupu z buňky se železo oxiduje na méně toxické železo trojmocné, vlastní oxidaci provádí molekula v membráně enterocytu nazývaná hephaestin. Železo vstupuje do krve, kde je př́tomen jeho specifický přenašeč - transferin. Navázané na molekulu transferinu je trojmocné železo hematogenní cestou distribuováno po celém těle. Jedna molekula transferinu může vázat až dva atomy železa.

\subsection{Distribuce železa v tělních tkáních}

Na rozdíl od jiných látek, metabolismus železa je z podstatné části uzavřený koloběh, $v$ rámci kterého je maximálně využíváno železo, v organismu již obsažené. Základ cyklu představuje recyklace železa ze zaniklých erytrocytů $v$ retikulo-endoteliálním systému. Denně toto množství představuje asi $20 \mathrm{mg}$, což je více než desetinásobek železa vstřebaného. Ústřední roli v procesu recyklace zaujímají makrofágy ve slezině, které fagocytují opotřebované erytrocyty. Hemoglobin je uvnitř makrofágů rozložen na proteinovou část globin a hem, ze kterého je uvolněno dvojmocné železo. Železo vystupuje z makrofágu ferroportinem, stejnou molekulou, která zabezpečuje jeho výstup ze střevní buňky. Oxidaci na $\mathrm{Fe}^{3+}$ zabezpečuje ceruloplasmin, plazmatický metaloprotein funkčně i strukturně podobný membránovému hephaestinu. Trojmocné železo se opět váže na svůj transportér transferin, který jej distribuuje po celém těle. Cyklickou část metabolismu železa, která představuje i kvantitativně největší část jeho obratu, je možné shrnout následovně. Kostní dřeň produkuje erytroblasty, ze kterých dozrávají erytrocyty. Červené krvinky obsahují největší část železa v těle, a to ve formě hemového železa. Staré erytrocyty jsou odbourávány v makrofágovém systému formou fagocytózy. Z makrofágů se železo uvolňuje, váže na plazmatický transferin, který opět přináší železo do kostní dřeně. Železo potřebují i další buňky v organismu, které ho rovněž získávají z transferinu. Játra navíc slouží i jako významná zásobárna železa, při jeho nedostatku by se z jater mohlo železo uvolňovat. Cyklus železa však není zcela uzavřený. Denně dochází ke ztrátám železa olupováním buněk, jde asi o 1 až 2 mg za den. Toto množství či jakákoliv zvýšená potřeba železa, je doplňováno adekvátním vstřebáváním železa $v$ duodenu. To je místo, kde je organismus schopen regulace množství železa $v$ těle, protože neexistuje žádná forma regulovaného výdeje železa.

\subsection{Systémová regulace metabolismu železa}

Hlavním systémovým regulátorem metabolismu železa je protein hepcidin. Hepcidin je syntetizován $v$ játrech a působí převážně v duodenu, kde snižuje vstřebávání železa. Dojde-li k nadbytku železa, produkce hepcidinu se zvýší a vstřebání železa v duodenu se sníží. Opačný stav by nastal při nedostatku železa. Hepcidin působí rovněž na makrofágy, které se podílejí na recyklaci železa ze starých erytrocytů. Zesílená produkce hepcidinu způsobí snížené uvolňování železa z makrofágů a železo se následně $v$ makrofázích hromadí. Tento proces může velmi rychle snízit plazmatickou koncentraci železa, protože recyklace železa je kvantitativně velmi významná.

Molekulárním mechanismem působení hepcidinu na enterocyty a makrofágy je inhibice exportéru železa, ferroportinu, formou jeho internalizace a degradace. Je-li produkce hepcidinu vysoká, nejsou buňky v důsledku sníženého množství ferroportinu v membráně schopny železo exportovat do krve. Železo se $v$ enterocytech a makrofázích hromadí. Enterocyt, který je naplněný železem, je po několika dnech odloučen ze sliznice a nedojde tak ke vstřebání železa do organismu. Naopak železo "uvězněné" v makrofágu v organismu zůstává, není však v danou chvíli dostupné pro další využití. Tento proces se nazývá sekvestrace železa v makrofázích.

Nadbytek hepcidinu má dva důsledky. Jednak rychlý pokles železa v séru díky jeho sekvestraci v makrofázích a utlumené recyklaci. Dlouhodobě dochází k absolutnímu nedostatku železa $v$ organismu, a to $v$ důsledku útlumu jeho resorpce v duodenu. Nedostatek či chybění hepcidinu má za následek trvale zvýšenou resorpci železa, jeho následný nadbytek a komplikace s tím spojené.

\subsection{Přenos železa z krve do buňky}

Vzhledem k tomu, že železo je díky svým fyzikálně-chemickým vlastnostem součástí mnoha různých enzymů, je obsaženo v různé miřre ve všech buňkách těla. Pro příjem železa má buňka na svém povrchu velké množství receptorů pro transferin. Na vyvíjejících se erytroblastech, které jsou hlavními odběrateli železa, jich může být až několik desítek či stovek tisíc. Na transferinový receptor se s vysokou specifitou váže transferin přenášející až dva atomy trojmocného železa. Po jeho navázání dochází k internalizaci železa do buňky endocytózou. Receptor s navázaným transferinem a železem se z povrchu buňky dostává do endozomu. $V$ něm dojde $k$ uvolnění železa $z$ transferinu, a to za pomoci sníženého $\mathrm{pH}$, které je zajištěno protonovou pumpou za spotřeby ATP. Trojmocné železo je v endozomu redukováno na dvojmocné a vystupuje z něj do cytoplasmy kanálem DMT1 - tím samým, kterým vstupuje dvojmocné železo do enterocytu v symportu s protonem. Transferinový receptor se pak navrací zpět na povrch buňky a uvolňuje vakantní transferin do krevního řečiště. $V$ buňce může železo vstoupit do mitochondrie, kde se stává součástí mnoha metaloproteinů. Vzhledem ke své toxicitě je nadbytek volného dvojmocného železa uložen do zásobní formy, tou je méně reaktivní trojmocná forma navázaná na bílkovinu ferritin. Ve ferritinu může být uloženo přes 4000 atomů železa.

\subsection{Vztah metabolismu železa a zánětu}

Bylo prokázáno, že metabolismus železa je výrazným způsobem modulován prítomností zánětlivého stavu, během kterého vzniká v organismu velké množství zánětlivých mediátorů a cy- 
tokinů. Jedním z nejvýznamnějších prozánětlivých cytokinů je interleukin-6 (IL-6), jehož vyplavení může být vyvoláno př́tomností lipopolysacharidů (LPS) v krvi, které jsou součástí buněčné membrány Gram-negativních bakterií. V játrech IL-6 stimuluje produkci reaktantů akutní fáze. Jedním z peptidů, které jsou v játrech vlivem IL-6 a Bmp6 (Bone morphogenetic protein 6) zvýšeně syntetizovány v reakci na infekci, je i hepcidin. Během zánětlivých stavů se proto produkce hepcidinu zvyšuje. Hepcidin následně sníži nejen resorpci železa ve střevě, ale zejména redukuje uvolňování železa $z$ makrofágů. To vede $\mathrm{k}$ rychlému poklesu koncentrace železa $v$ séru. Pokles sérové koncentrace železa a pokles koncentrace transferinu jsou typické změny v metabolismu železa nastávající při zánětlivých stavech. Vyvíjejí se poměrně rychle $a$ jsou charakteristické pro tzv. anémii chronických chorob, $k$ jejíž patogenezi přispívají. Tato anémie provází četné zánětlivé stavy, nádorová onemocnění apod. Mimo jiné je charakterizována nedostatkem disponibilního železa pro erytropoezu. Biologickým smyslem snížení sérové koncentrace železa je fakt, že železo je významným a nezbytným prvkem nejen pro lidský organismus, ale i pro bakterie. Bakterie potřebují železo ke svému metabolismu a při infekci ho musí získat z tkání svého hostitele. Mají k tomuto účelu vyvinuty různé mechanismy. Lidský organismus se snaží bakteriím přístup k železu zamezit a inhibovat tak jejich množení. Rychlá sekvestrace železa makrofágy a snížení jeho sérové koncentrace $v$ důsledku zvýšené tvorby hepcidinu může být jedním z mechanismů, které $\mathrm{k}$ tomu slouží. Bakterie se následně méně množí a mohou být likvidovány imunitním systémem.

\section{Výuková aplikace}

Cílem práce bylo implementovat $v$ současné době nejkomplexnější matematický model metabolismu železa ([1]) v jazyce Modelica a s použitím námi vyvinutého nástroje BodyLight.js $([2,3])$ připravit interaktivní grafický simulátor pro potřeby výuky. Složitost metabolických drah regulace železa není triviální. Smyslem vyvíjeného výukového simulátoru je vysvětlit interaktivní formou vztahy metabolismu železa nejen na úrovni buňky, ale i jednotlivých orgánových systémů. Pro znázornění vztahů byly využity standardní biochemické symboly, které studenti znají z moderních učebnic. Výhodou interaktivního simulátoru je, mimo jiné, možnost jeho spuštění v běžném internetovém prohližeči na počítači nebo chytrém telefonu, a to bez nutnosti instalace jakékoliv aplikace nebo rozšírení. Vlastní matematický model a jeho simulační parametry jsou v rámci prostředí BodyLight.js zakomponovány společně s grafickou částí do jednoho standardizovaného HTML souboru. Zásadní výhodou je i možnost použití interaktivního simulátoru jako rozšíření e-learningových výukových prostředí jako jsou WikiSkripta, Moodle, apod.

Před prezentací vlastních výukových bloků bychom rádi ozřejmili myšlenku a princip zobrazení výsledků numerického modelu. Základní dva parametry, které model počítá jsou celková množství (resp. koncentrace) jednotlivých molekulárních entit v daném orgánu (atomů železa, enzymů, apod.) a příslušné toky, odpovídající změnám příslušného množství $v$ čase a prostoru. Toky jsou v grafických schématech reprezen-

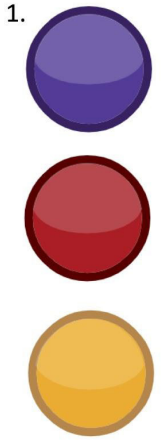

2.

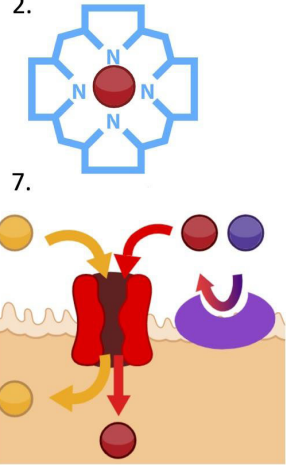

3.

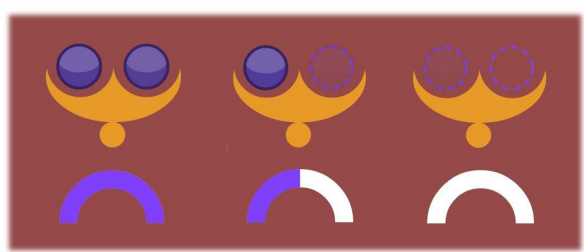

8.

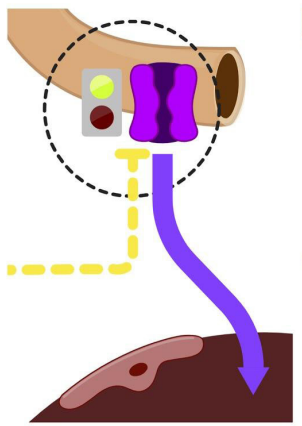

4.

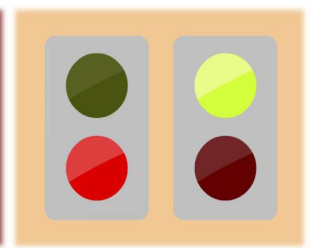

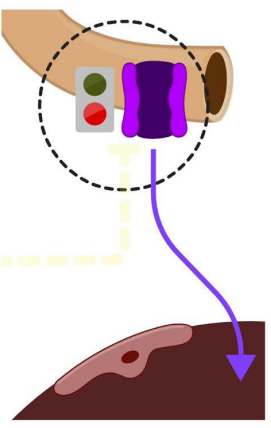

5.

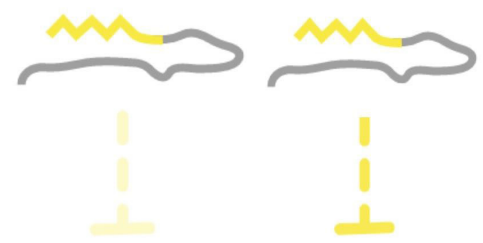

Obrázek 2 - Vysvětlení použitých grafických symbolů. 1. Reprezentace atomů: modrá - Fe ${ }^{3+}$, červená - Fe ${ }^{2+}$, žlutá - $H^{+}$. 2. Molekula hemu (modře tetrapyrolový kruh s centrálním atomem Fe ${ }^{2+}$ ). 3. Molekula transferinu se dvěma pozicemi pro navázání Fe ${ }^{3+}$ a odpovídající indikátor saturace. vlevo: plné nasycení (holo-transferin), uprostřed: $50 \%$ nasycení s navázaným jedním atomem Fe ${ }^{3+}$, vpravo: transferin bez navázaného Fe ${ }^{3+}$ (apo-transferin). Postupné sycení transferinu je v animované ikoně znázorněno kontinuálním zaplňováním pozic. 4. Ikona semaforu: v prípadě funkčního (zapnutého) genu pro ferroportin nebo hepcidin svítí zelená (vpravo), v prípadě deaktivace (knock-out) daného genu svítí červená (vlevo). 5. Míra inhibice procesu je zobrazena pomocí průsvitnosti čárkované linie, vlevo: mírná inhibice hepcidinu, vpravo: silná inhibice hepcidinu. 6. Množství transmembránových kanálů (ferroportinu) je reprezentováno mírou otevření přislušné ikony: horní - kanál silně otevřen = vyšší koncentrace kanálu v membráně, dolní - kanál téměř uzavřen = minimální koncentrace kanálu v membráně. 7. Ukázka části schématu č. 1: v kartáčovém lemu duodenálního enterocytu se nacházejí dva proteiny, červený transportér dvojmocných kovů (DMT1) a enzym cytochrom B (CytB). CytB redukuje Fe ${ }^{3+}$ na Fe ${ }^{2+}$, které společně s $H^{+}$vstupuje symportem přes DMT1 do nitra buňky. 8. Ukázka části schématu č. 2: Vlevo - transportér na bazolaterální membráně duodenálního enterocytu (feroportin) je téměř uzavřen díky silné inhibici hepcidinu. Tok železa z duodena do krve je významný. Zelené světlo na ikoně semaforu značí, že přislušný gen pro jeho tvorbu je aktivní. Vpravo - přestože je kanál široce otevřen díky slabé inhibici hepcidinem, tok železa do krve je zanedbatelný. Červené světlo na ikoně semaforu značí inaktivaci genu pro tvorbu kanálu. To se projeví jeho postupným uzavíráním, které odpovídá snižení jeho koncentrace v membráně. Po kliknutí kdekoliv uprostřed černé čárkované kružnice kolem transportéru student přejde do simulace príslušné oblasti (Obrázky 4-6). 


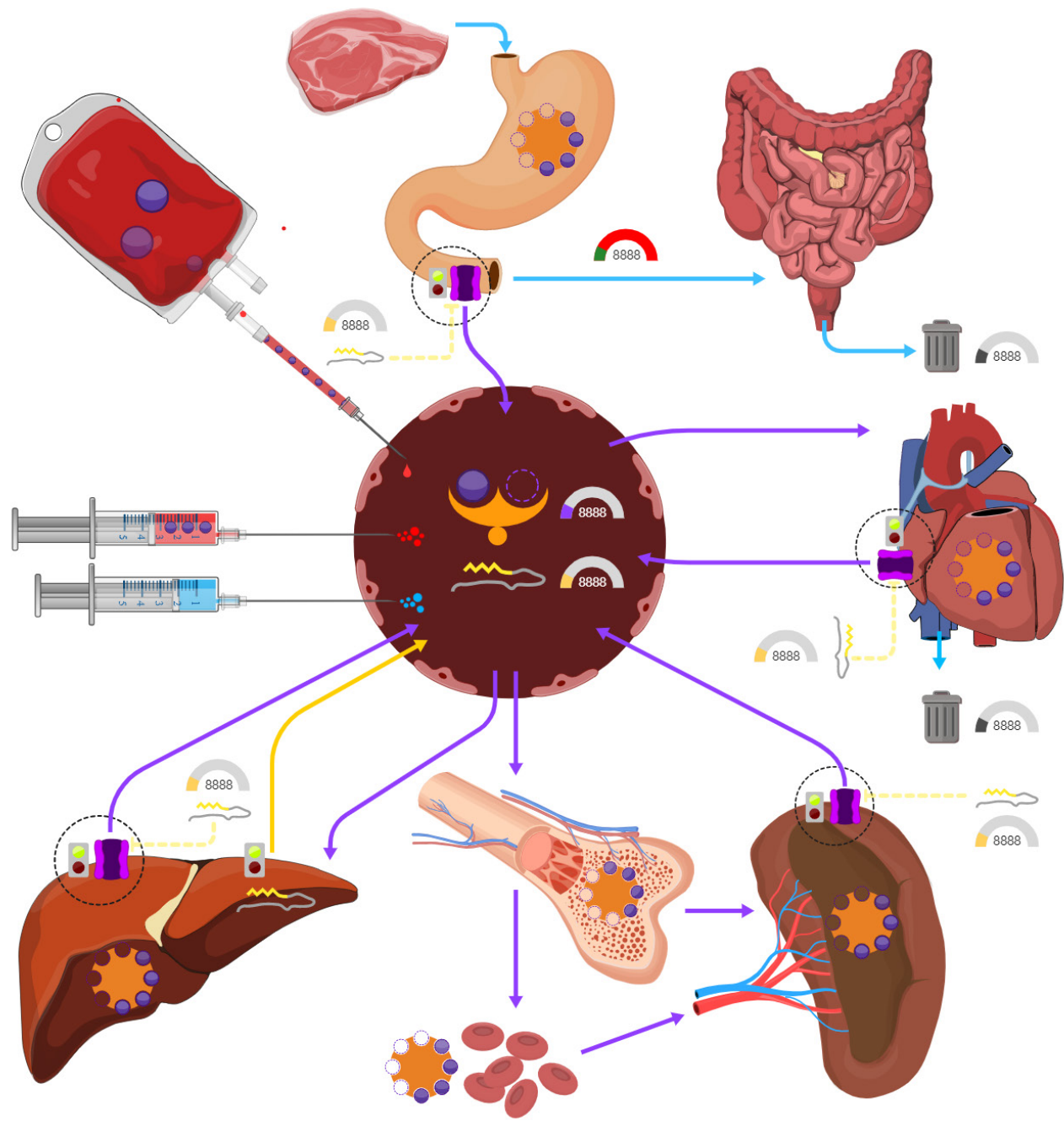

Obrázek 3 - Interaktivní animace systémové regulace metabolismu železa. Plné šipky značí reálný tok, čárkované označují inhibici (tupé T-zakončení). Kuličky reprezentuji atomy: $\mathrm{Fe}^{3+}$ (modré). Ferritin: ikona tvaru revolverového zásobníku, množství železa v dané tkáni je mapováno jako počet nábojů v zásobníku. Míra otevření transportního kanálu odpovídá množství proteinu v membráně. Transportní kanály: ferroportin (fialový). Injekční střikačka s modrou náplní reprezentuje lipopolysacharid (LPS), vyvolávající systémovou zánětlivou odpověd'. Nasávající injekční stríkačka s krví reprezentuje odběr/ztráty krve, krevní vak naopak doplněnípříjem krve. Součástí krvejsou: hepcidin (žluto-šedý) a transferin (oranžovýs dvěma vazebnými místy pro navázání Fe $e^{3+}$ ). Ztráty železa jsou symbolizovány odpadkovým košem. Ikony semaforů indikují prípadný genový knock-out pro hepcidin (pouze v játrech) a ferroportin v různých částech těla.

továny plnými šipkami s ostrými hroty, kdy každá šipka má tři parametry: i) tloušt'ka šipky odpovídá velikosti toku v absolutní hodnotě, ii) poloha hrotu charakterizuje směr toku a iii) barva šipky vypovídá o přenášené entitě (např. modrá šipka odpovídá přenosu $\mathrm{Fe}^{3+}$, který je reprezentován modrou barvou). V grafických schématech se dále objevuji přerušované/čárkované šipky, které reprezentují regulaci procesu. $V$ prípadě tupého "T-zakončení" se jedná o inhibici procesu, v případě ostrého zakončení hrom aktivaci. Míra aktivace nebo inhibice je zobrazena pomocí průsvitnosti čar. Neprůsvitná čárkovaná šipka s tupým zakončení odpovídá maximální inhibici a naopak, sotva viditelná přerušovaná šipka s ostrým hrotem odpovídá slabé aktivaci. Pro vysvětlení použité nomenklatury, viz Obrázek 2.

Matematický model reprezentuje organismus pomocí šesti kompartmentů, mezi kterými probíhá transfer železa: duodenum, játra, slezina, kostní dřeň, erytrocyty a ostatní buňky. Prostředí pro výměnu představuje sedmý kompartment - krevní plazma a $v$ ní rozpuštěný přenašeč železa, transferrin. Vlastní model je složen z př́slušných nelineárních diferenciálních rovnic popisujících kinetiku toků železa mezi kompartmenty, parametry modelu byly fitovány na dostupná experimentální data. Numerickým řešením soustavy diferenciálních rovnic do- stáváme časový vývoj množství železa a jiných entit v jednotlivých orgánových systémech. Fyziologický zdroj železa je jeden - potrava. Množství železa v těle je možné dále regulovat aplikací krevní infuze (nefyziologický zdroj železa), čímž se zvyšuje celkové množství železa v kompartmentu krevní plazmy (železo vázané na transferrin) a erytrocytech (hemové železo). Fyziologické ztráty železa jsou tři: i) železo přijaté v potravě, které nebylo vstřebáno, ii) krevní ztráty a iii) deskvamace buněk. V rámci výukové aplikace je možné príslušné parametry regulující přísun a ztráty železa v reálném čase měnit a sledovat odezvu adaptujícího se organismu, včetně meziorgánových přesunů. $\checkmark$ rámci simulace patologických stavů je možné $v$ simulátoru navodit prozánětlivý stav injekcí LPS (bakteriálního endotoxinu) do krevního řečiště. Endotoxin vede k nárůstu koncentrace IL-6 a Bmp6, které v jaterních hepatocytech zvyšují expresi genu pro hepcidin. Dále simulátor umožňuje provést virtuální genový knock-out, tj. inaktivaci genu pro hepcidin (játra) a ferroportin (duodenum, játra, slezina, ostatní buňky) a pozorovat odpovídající reakci organismu.

\subsection{Systémový pohled}

Na Obrázku 3 je znázorněna dynamika přenosu železa na sys- 


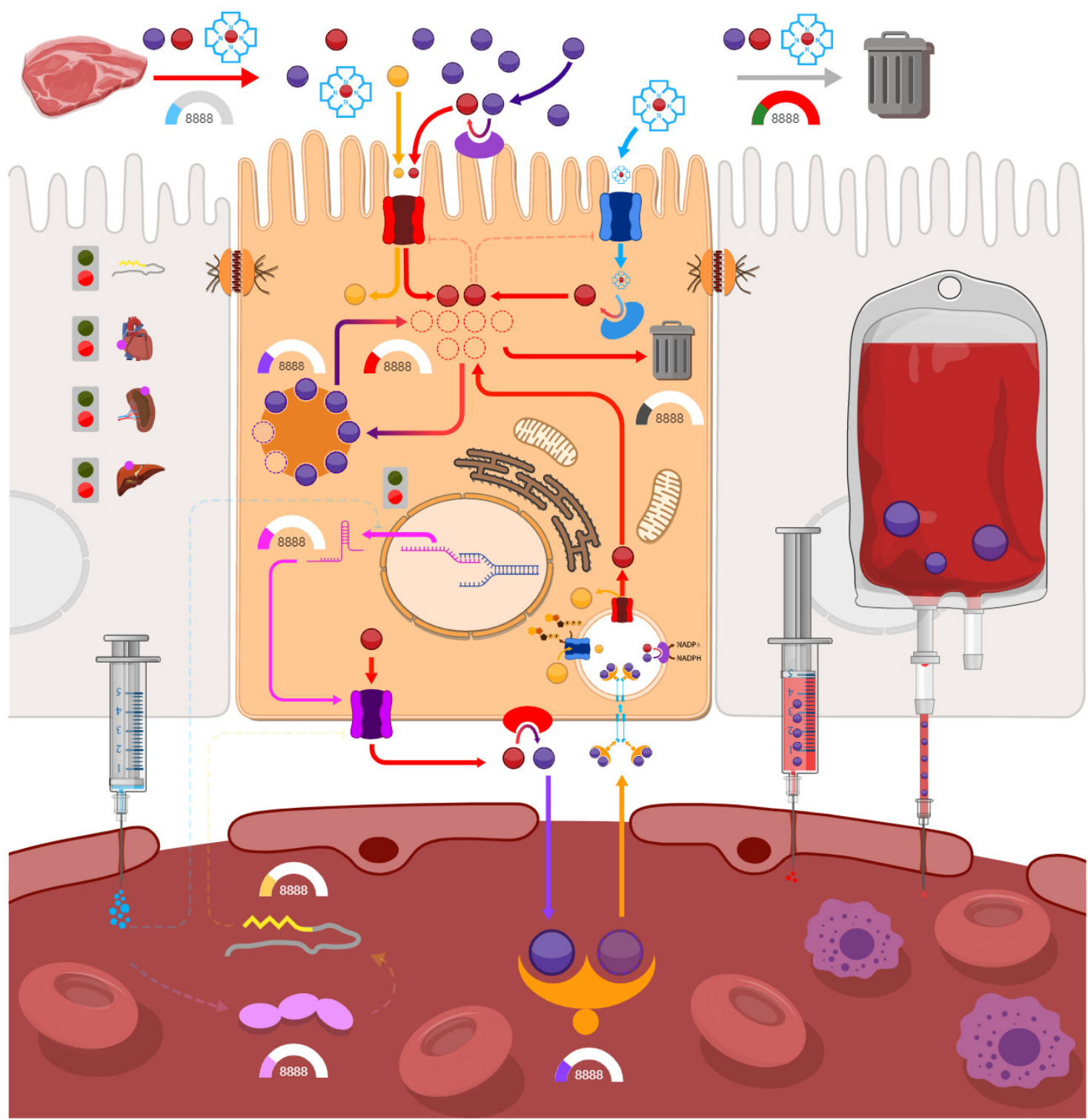

Obrázek 4 - Interaktivní animace príjmu železa a jeho vstřebánív duodenu. PIné šipky značír reálný tok, čárkované označují aktivaci (ostré zakončení) a inhibici (tupé T-zakončení). Kuličky reprezentuji atomy: $\mathrm{Fe}^{2+}$ (červené), $\mathrm{Fe}^{3+}$ (modré), $\mathrm{H}^{+}$(žluté). Hem je zakreslen jako Fe ${ }^{2+}$ uprostřed modrého porfyrinového kruhu. Ferritin: ikona tvaru revolverového zásobníku. Míra otevření transportního kanálu odpovídá množství proteinu v membráně. Transportní kanály: DMT1 (červený), hemový transportér (modrý), ferroportin (fialový, bazolaterálně). Injekční stříkačka s modrou náplní reprezentuje lipopolysacharid (LPS), vyvolávající systémovou zánětlivou odpověd. Nasávající injekční střikačka s krví reprezentuje odběr/ztráty krve, krevní vak naopak doplnění/přijem krve. Součástí krve jsou: hepcidin (žluto-šedý), IL-6 (fialový) a transferin (oranžovýs dvěma vazebnými místy pro navázání Fe ${ }^{3+}$ ). Ztráty železa jsou symbolizovány odpadkovým košem. Ikony semaforů indikují prípadný genový knock-out pro hepcidin a ferroportin v různých částech těla.

témové úrovni. Železo je přijímáno organismem v potravě, převážně v mase. Velikost př́ijmu potravy (a tedy příjmu železa) může uživatel $v$ simulátoru ručně regulovat pomocí táhla. V oblasti duodena prochází část železa apikální a následně bazolaterální membránou enterocytu a přes ferroportinový kanál (fialový) vstupuje do krevního řečiště, kde je navázáno na molekulu transferinu (oranžová ikona uvnitř cévy). Indikátor napravo od ikony reprezentuje množství železa v krevní plazmě. Zbylá, nevstřebaná část železa, pokračuje trávicí trubicí a nepoužita je vyloučena z těla. Poměr vstřebaného a nevstřebaného železa je dopočítáván a zpětnovazebně řízen. Uživatel může manuálně snižovat absorpční plochu pro vstřebávání, čímž simuluje chirurgickou resekci duodenální etáže trávicí trubice. Železo vázané na transferin může dále přecházet do následujících orgánů: i) jater, které fungují jako zásobárna železa, ii) kostní dřeně, kde je následně použito pro vznik červených krvinek, a iii) ostatních buněk těla (reprezentováno ikonou srdce). Ke ztrátám železa dochází právě z kompartmentu ostatních buněk. Z jater, sleziny (resp. makrofágového systému) a ostatních buněk může přecházet železo i zpět do krve prostřednictvím feroportinového přenašeče (fialový kanál na zmíněných orgánech). Ikona semaforu značí aktivaci (zelená) nebo inaktivaci (červená) genu pro ferroportin ve tkáních př́slušného orgánu. V orgánech je železo uloženo převážně ve formě ferritinu. Ten představuje dynamická oranžová ikona ve tvaru zásobníku revolveru, kdy počet nábojů odpovídá množství železa v daném kompartmentu. $\mathrm{V}$ lumen cévy je dále znázorněna ikona hepcidinu (žluto-šedá). Hepcidin je tvořen v játrech a exportován do krve (plná žlutá šipka). Malá ikona hepcidinu je pro přehlednost znázorněna u feroportinových přenašečů, které hepcidin inhibuje (žlutá čárkovaná šipka s T-koncem). Krevní vak reprezentuje krevní transfuzi, jejíz rychlost může uživatel ručně měnit. Injekce s modrou náplní symbolizuje LPS vyvolávající zánět, injekce nasávající krev představuje ztráty krve (a železa). Rychlost krevních ztrát je možné manuálně regulovat. 


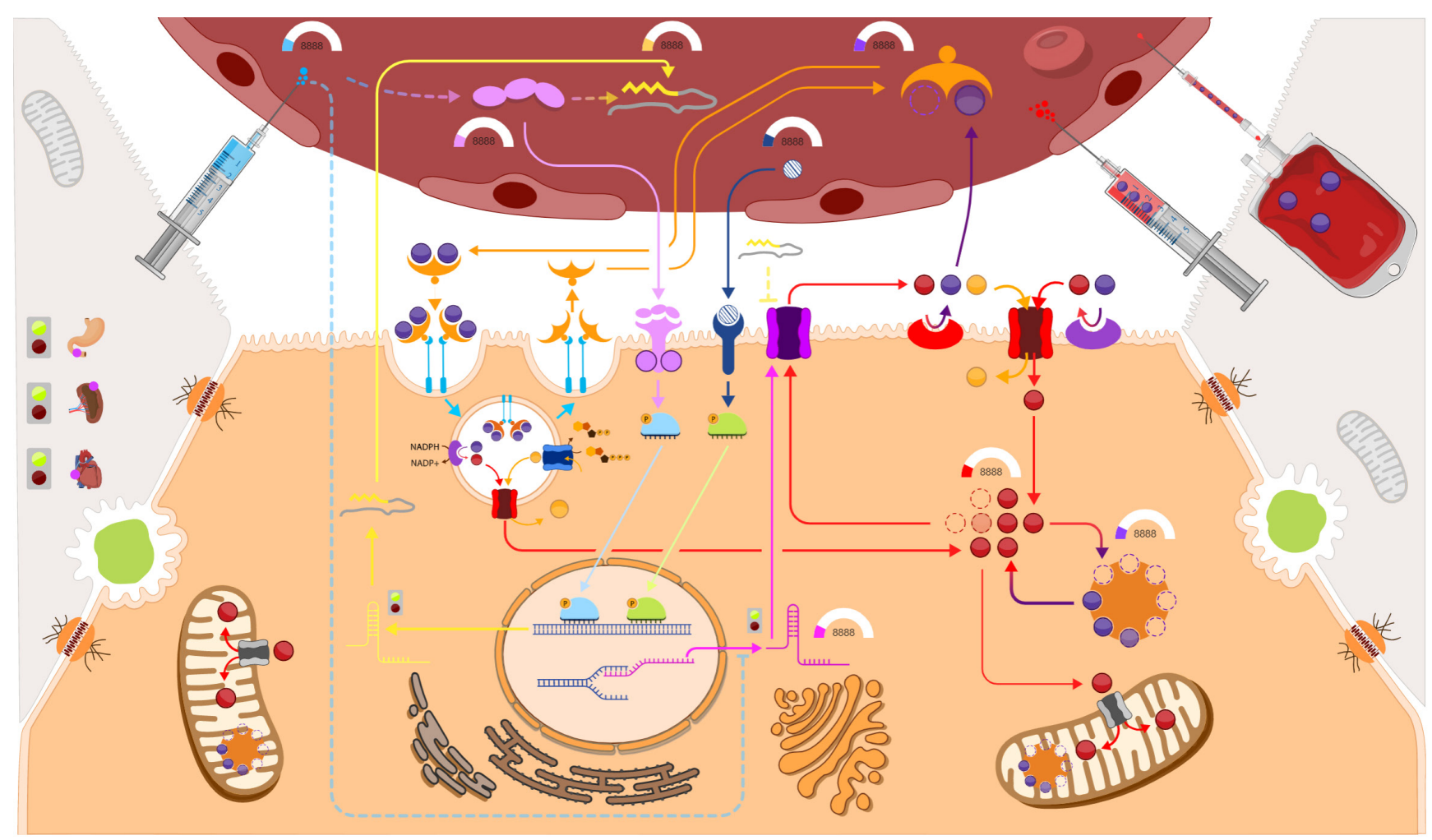

Obrázek 5 - Interaktivní animace regulace a toku železa na úrovni hepatocytu v játrech. Plné šipky značí reálný tok, čárkované označují aktivaci (ostré zakončení) a inhibici (tupé T-zakončení). Kuličky reprezentují atomy: Fe ${ }^{2+}$ (červené), Fe $e^{3+}$ (modré), $H^{+}$(žluté). Ferritin: ikona tvaru revolverového zásobníku. Míra otevření transportního kanálu odpovídá množství proteinu v membráně. Transportní kanály: DMT1 (červený), ferroportin (fialový). Injekční stříkačka s modrou náplní reprezentuje lipopolysacharid (LPS), vyvolávající systémovou zánětlivou odpověd. Nasávající injekční stříkačka s krví reprezentuje odběr/ ztráty krve, krevní vak naopak doplnění/príjem krve. Součástí krve jsou: hepcidin (žluto-šedý), IL-6 (fialový), transferin (oranžový s dvěma vazebnými místy pro navázání $\mathrm{Fe}^{3+}$ ) a Bmp6 (modře). Ikony semaforů indikují případný genový knock-out pro hepcidin a ferroportin v různých částech těla.

\subsection{Duodenum}

Na Obrázku 4 je grafická reprezentace modelové simulace metabolismu železa v duodenálním enterocytu. Na apikální membráně s klky dochází k resorpci železa, které se vyskytuje ve třech různých formách: i) dvojmocné (červené), ii) trojmocné (modré), a iii) hemové (s porfyrinem) železo. Jistá část železa se nevstřebá, pokračuje trávicí trubicí (šedá šipka) a je vyloučena stolicí (odpadkový koš). Zeleno-červený indikátor pod šedou šipkou znázorňuje poměr mezi vstřebaným a vyloučeným železem. Tlouštka šipek se dynamicky mění v závislosti na aktuální velikosti príslušného toku. $V$ enterocytu existuje pool volného dvojmocného železa, většina atomů je však v trojmocné oxidované formě deponována ve ferritinu. Mezi ferritinem $\left(\mathrm{Fe}^{3+}\right)$ a volným železem $\left(\mathrm{Fe}^{2+}\right)$ existuje dynamická rovnováha posunutá silně ve prospěch zásobní formy. Výstup železa z buňky je řízen množstvím ferroportinových přenašečů na bazolaterální membráně (fialový kanál). Inhibice transportu železa z buňky je zajištěna na dvou různých úrovních: i) LPS inhibuje transkripci feroportinové mRNA (světle modrá čárkovaná čára) a ii) LPS indukuje vznik IL-6, který vede ke zvýšení koncentrace hepcidinu. Hepcidin následně blokuje ferroportin. Dvojmocné železo po své oxidaci hephaestinem (červený enzym na bazolaterální straně) přechází do krve, kde se váže na transferin. Enterocyt, stejně jako jakákoliv jiná buňka, má receptory pro transferin a může tak přijímat železo také z krve. Tento metabolický kanál však není významný a často se neuvádí. Podobně jako v př́ípadě systémového obrazu může i zde uživatel sledovat reakci duodenálního enterocytu na podání LPS, na prísun a ztráty krve, a především na velikost př́imu železa potravou.

\subsection{Játra}

Na Obrázku 5 je znázorněna nejkomplexnější regulační sít’ v rámci metabolismu železa, $v$ jaterním hepatocytu. Na rozdíl od enterocytu, $v$ duodenu není rozlišena apikální a bazolaterální membrána, a všechny príslušné receptory a transportéry jsou umístěné na membráně přivrácené ke kapilárnímu řečišti. Ikony dané barvy mají stejný význam jako v prípadě duodena. $\mathrm{Na}$ membráně jsou navíc receptory pro IL-6 (světle fialová) a Bmp6 (tmavě modrá). V obou případech se jedná o kinázy, které aktivují transkripční faktory hepcidinu. Společným působením IL-6 a Bmp6 dojde k expresi genu pro hepcidin, který je uvolněn do krve (žlutá plná šipka). Uživatel může příslušný gen pro hepcidin vypnout (ikona semaforu), sledovat odezvu systému a simulovat tak experimentální genový knock-out vedoucí klinicky k těžkému přetížení železem (hereditární hemochromatóza). Volné železo (červené) přechází i) do své zásobní ferritinové formy v prípadě jeho vyšší koncentrace v krvi, ii) přes ferroportin do krve, $v$ prípadě jeho systémového nedostatku a iii) do mitochondrií, kde je využito pro tvorbu metaloproteinů. Ikonky semaforů v pravé části obrázku připomínají uživateli, ve kterých orgánech je zapnuta/vypnuta exprese ferroportinu.

\subsection{Ostatní buňky}

Všechny ostatní buňky těla, které nemají významnější funkci ve vztahu k metabolismu železa, jsou schematicky znázorněny na Obrázku 6 ve formě nespecifické buňky. Význam jednotlivých ikonek je shodný s předcházejícími obrázky. Podobně jako u duodenálních enterocytů jsou i zde možné ztráty železa (ikona odpadního koše), nebot' jsou buňkou reprezentovány např́klad i keratocyty, jejichž deskvamací dochází ke ztrátám železa. Kromě vázaného hephaestinu, který oxiduje dvojmocné železo na trojmocné, je zde schematicky znázorněn i rozpustný ceruloplasmin, který plní obdobnou funkci. 


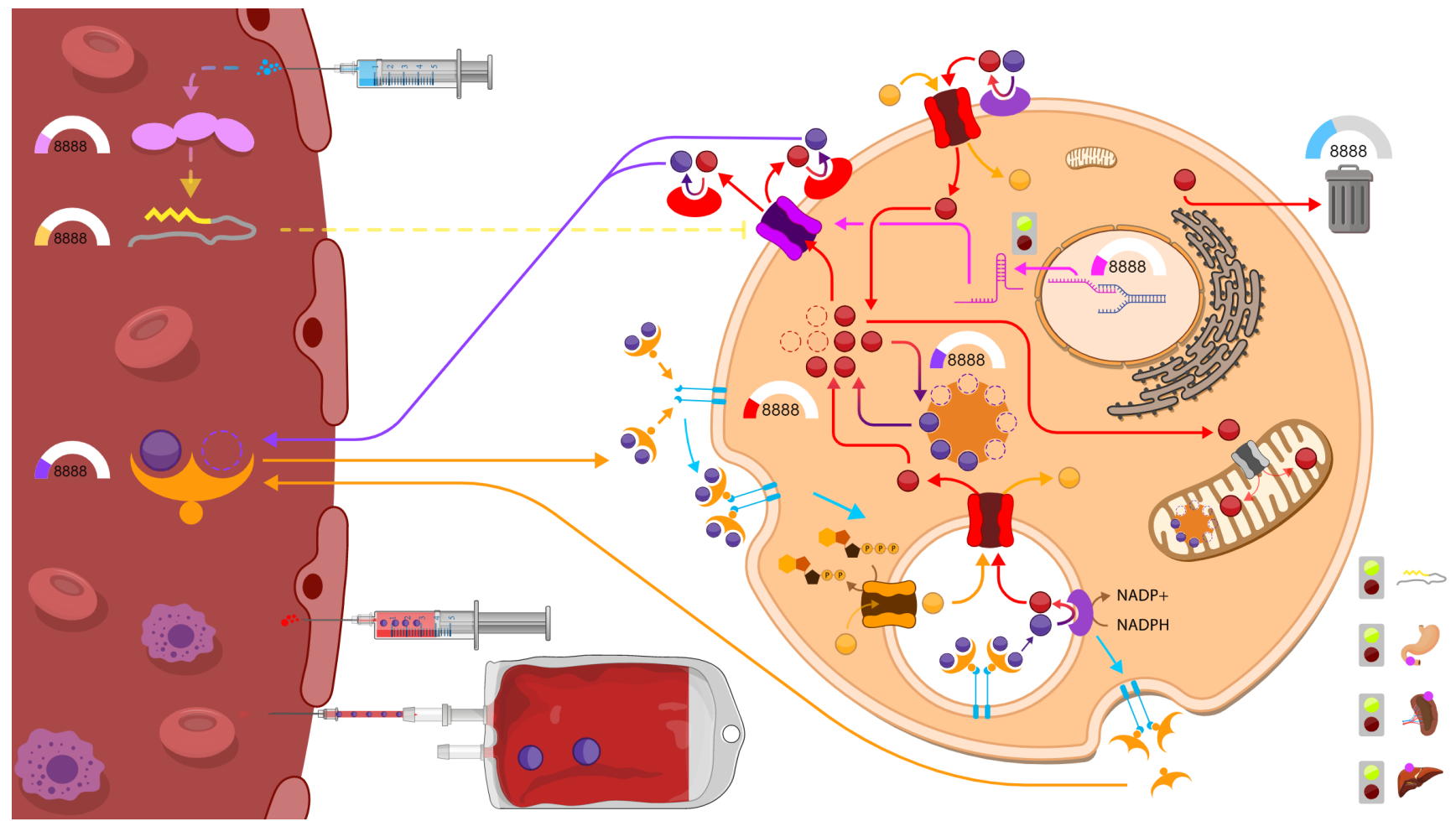

Obrázek 6 - Interaktivní animace regulace a toku železa na úrovni běžných buněk. Plné šipky značí reálný tok, čárkované označují inhibici (tupé T-zakončení). Kuličky reprezentuji atomy: $\mathrm{Fe}^{2+}$ (červené), $\mathrm{Fe}^{3+}$ (modré), $\mathrm{H}^{+}$(žluté). Ferritin: ikona tvaru revolverového zásobníku. Míra otevření transportního kanálu odpovídá množství proteinu v membráně. Transportní kanály: DMT1 (červený), ferroportin (fialový). Injekční stř́kačka s modrou náplní reprezentuje lipopolysacharid (LPS), vyvolávající systémovou zánětlivou odpověd. Nasávající injekční stř́kačka s krví reprezentuje odběr/ztráty krve, krevní vak naopak doplnění/príjem krve. Součástí krve jsou: hepcidin (žluto-šedý), IL-6 (fialový) a transferin (oranžový s dvěma vazebnými místy pro navázání Fe ${ }^{3+}$ ). Ikony semaforů indikují prípadný genový knock-out pro hepcidin a ferroportin v různých částech těla.

\section{Zkušenosti z vývoje}

Motivace pro vytvoření pilotní výukové aplikace metabolismu železa v prostředí BodyLight.js byla trojí: i) studium regulace železa má na ústavu patologické fyziologie dlouholetou tradici je mu věnována značná experimentální pozornost, ii) regulace železa je klíčová pro správné fungování organismu a její poruchy vedou k závažným klinickým stavům (sideropenická anémie, hemochromatóza, apod.) a iii) metabolismus železa je složitý proces, který často dělá studentům medicíny problémy. Zvláště u posledního bodu - je zde snaha primárně o pochopení základních principů regulace, které jde v ruku v ruce se schopností studenta aplikovat poznatky a predikovat reakci organismu na různé patologické stavy. Právě zde se otevírá prostor pro využití moderních interaktivních technologií, které ilustrativním způsobem ozřejmují základní principy. Student tak může interaktivně vstupovat do řízení metabolismu, snažit se udržet fyziologickou hladinu železa za různých patologických scénářů a ověřit si, zda správně pochopil klíčové vztahy. V neposlední řadě si může student simulovat různé experimentální situace, jako je např́ílad genový knock-out studovaný na laboratorních zvíratech.

Z didaktických důvodů budou jednotlivé dráhy jednotlivých modulů (Obrázek 3-6) odkrývány postupně ve shodě s učebním textem. Student se tak zaměří na konkrétní proces a po porozumění jeho principu mu bude odkryt následující. Po pochopení všech dílčích mechanismů pak v posledním kroku bude student pracovat s kompletním modulem tak, jak jsou zobrazeny na Obrázku 3-6. Doprovodný text bude doplněn krátkými popisy jednotlivých entit, které se zobrazí po označení kurzorem.

Výuková aplikace metabolismu železa je $v$ tomto rozsahu první svého druhu a jedná se o pilotní verzi, která bude dále rozšiřována a upravována a to především na základě vlastních zkušeností pedagogů z reálného nasazení ve výuce a zpětné vazby od studentů. Paralelně s vývojem výukových aplikací probíhá i kontinuální rozšiřování vlastní platformy BodyLight. js o další funkcionality. Zdrojem podnětů jsou často uživatelé aplikace - predevším studenti medicíny.

Výuková aplikace je na adrese: http://physiome.cz/apps/ IronMetabolism

\section{Závěr}

Metabolismus železa je nedílnou součástí sylabu výuky biochemie a (pato)fyziologie na lékařské fakultě. Znalost jeho základních principů je nezbytná pro hlubší porozumění celého spektra interních onemocnění souvisejících s poruchou regulace metabolismu železa na různých úrovních. Za účelem lepšího pochopení komplexních vztahů u studentů všeobecného lékařství jsme převzali kompartmentový matematický model systémové dynamiky železa a připravili moderní výukovou aplikaci, která stojí na třech piliríích:

1. Implementace složitého matematického modelu v jazyce Modelica.

2. Příprava intuitivního grafického prostředí ve spolupráci s týmem grafiků.

3. Konstrukce výukových modelů v námi vyvinuté platformě BodyLight.js.

Jedná se rozsahově o první větší aplikaci tohoto druhu, která je nasazena $\mathrm{v}$ rámci povinné výuky patologické fyziologie na 1. LF UK. Kritická zpětná vazba od studentů je pro nás motivací a pomáhá nám selektivně rozvíjet nejen samotnou aplikaci, ale predevším rozšiřovat nástrojové možnosti vývojové platformy BodyLight.js. Fakt, že bez společného úsilí fyziologů/pedagogů, matematiků, programátorů a grafiků by prezentovaná aplikace nemohla vzniknout, dokládá zásadní prínos multioborového týmu. 


\section{Literatura}

[1.] Enculescu M, Metzendorf C, Sparla R, Hahnel M, Bode J, Muckenthaler MU, et al. Modelling Systemic Iron Regulation during Dietary Iron Overload and Acute Inflammation: Role of Hepcidin-Independent Mechanisms. PLoS Comput Biol. 2017;13: e1005322.

[2.] Šilar J, Polák D, Mládek A, Ježek F, Kurtz TW, DiCarlo SE, et al. Development of In-Browser Simulators for Medical Education: Introduction of a Novel Software Toolchain. J Med Internet Res. 2019;21: e14160.

[3.] Šilar J, Ježek F, Mládek A, Polák D, Kofránek J. Model visualization for e-learning, Kidney simulator for medical students. Proceedings of the 13th International Modelica Conference, Regensburg, Germany, March 4-6, 2019. Linköping University Electronic Press; 2019. pp. 393-402.

\section{Kontakt:}

RNDr. Mgr. et Mgr. Arnošt Mládek Ph.D.

Oddělení biokybernetiky,

Ústav patologické fyziologie 1. LF UK

e-mail:arnost.mladek@gmail.com 